\title{
Induction of differentiation and apoptosis by interferon- $\gamma$ in human neuroblastoma cells in vitro as a dual and alternative early biological response
}

\author{
Paolo Giuseppe Montaldo ${ }^{1,4}$, Valeria Chiesa ${ }^{1}$, \\ Massimo Bado ${ }^{2}$, Lizzia Raffaghello ${ }^{1}$, Carla Rozzo ${ }^{3}$ and \\ Mirco Ponzoni ${ }^{1}$ \\ ${ }^{1}$ Laboratory of Oncology, G. Gaslini Children's Hospital, Largo G. Gaslini 5, \\ 16148, Genoa, Italy \\ 2 Muscle Disorder Unit, G. Gaslini Children's Hospital, Largo G. Gaslini 5, 16148 \\ Genoa, Italy. \\ ${ }^{3}$ Molecular Genetics Institute, National Research Council, Alghero, Italy \\ ${ }^{4}$ corresponding author: Laboratory of Oncology, G. Gaslini Children's Hospital, \\ Largo G. Gaslini 5, 16148, Genoa, Italy
}

Received 8.7.96; revised 22.8.96; accepted 26.8.96

Edited by: R.A. Knight

\begin{abstract}
Interferon- $\gamma$ (IFN- $\gamma)$ has a well known differentiation-promoting activity on several neuroblastoma (NB) cell lines and has also been reported to induce apoptosis in different cellular models. We have investigated the potential of IFN- $\gamma$ to trigger, besides differentiation, programmed cell death in NB cells and the relationship between these processes. Nine NB cell lines, characterized by different phenotypic and maturational features, were cultured in the presence of IFN- $\gamma(1000 \mathrm{IU} / \mathrm{ml})$ for up to 5 days with either only one treatment at the start of the culture or renewing the culture medium (with or without IFN- $\gamma$ ) every other day. Neuronal differentiation was assessed by evaluation of morphological changes and expression of mature cytoskeletal proteins, while apoptosis was evaluated at the desired times by fluorescent and electronic microscopy, DNA content analysis and DNA fragmentation assay. Our findings show that apoptosis is an early (mainly non postdifferentiative) event and is much more evident following a single IFN- $\gamma$ administration. Moreover, IFN- $\gamma$-triggered apoptosis is independent of the cellular phenotype (schwannian or neuronal) and appears to be mutually exclusive with respect to differentiation at the single cell level. Our results strengthen the potential of IFN- $\gamma$ as a promising therapeutic agent for NB.
\end{abstract}

Keywords: neuroblastoma, interferon- $\gamma$, differentiation, apoptosis

Abbreviations: IFN- $\gamma$, Interferon- $\gamma$; NB, neuroblastoma; NGF, nerve growth factor; TNF, tumor necrosis factor; MAP, microtubule-associated proteins; EDTA, ethylenediaminetetracetic acid; PBS, phosphate buffered saline

\section{Introduction}

Interferons are cytokines endowed with a pleiotropic spectrum of biological properties, including immunomodulation, antiviral and proinflammatory activity. Moreover, in some normal and transformed cellular types, they promote cellular differentiation and partial or total reversion of the malignant phenotype. We and others have previously reported that interferon- $\gamma$ (IFN$\gamma)$ is very effective in inhibiting cellular growth and inducing terminal differentiation of some neuroblastoma (NB) cell lines (Parodi et al, 1989; Wuarin et al, 1991; Ponzoni et al, 1992), and suggested a differentiation-based therapeutic regimen for human neuroectodermal tumors as a potential alternative or additional tool besides more traditional and still unsatisfactory cytostatic strategies. Growth, differentiation and apoptosis are alternative cellular pathways, each crucial to normal development and establishment of tissue-specific functions. Recent evidence suggests that the failure of cells to undergo apoptotic death could be involved in the pathogenesis of a variety of human diseases, including autoimmune disorders, viral infections and cancer (Thompson, 1995; Steller, 1995; Williams, 1991).

Programmed cell death or apoptosis is an active phenomenon requiring a coordinate program of gene activation and transcription which eventually leads to cell death without loss of intracellular contents and, consequently, no damage to surrounding cells and tissues. This type of cell death is characterized by a series of morphological and biochemical events including plasma membrane blebbing, chromatin and cytoplasmic condensation with progressive cellular shrinkage and a characteristic internucleosomal DNA degradation into small fragments of about 200 base pairs. Throughout the process, cell integrity is maintained and the apoptotic cell is eventually phagocytosed. Apoptosis is a physiological mechanism whereby developing tissues and organs reach the appropriate cell number during embryogenesis and maintain their homeostasis during adulthood. On the other hand, it has been proposed that tumor progression can result not only from excessive cell proliferation, but even from aberrant cell survival due to inappropriate suppression of apoptosis (Marx, 1993). Moreover, since it has been suggested that the cytostatic activity exerted by several antineoplastic drugs takes place through induction of tumor cell apoptosis (Dive et al, 1991; Lowe et al, 1993), the induction of programmed cell death in tumor cells is clearly a therapeutic aim.

A variety of drugs and biological agents have been reported to induce differentiation or apoptosis in NB cells (Abemayor and Sidell, 1989; Ponzoni et al, 1992, 1995; Piacentini et al, 1992; Montaldo et al, 1994). Therefore, NB cell lines are suitable models for investigation of the mechanisms of neuronal death and its relation to differentiation (Piacentini et al, 1992; Hanada et al, 1993; Melino et al, 1994). Recently, interferons have been reported to modulate apoptosis positively or negatively depending on the cell and experimental system investi- 
gated (Lotem and Sachs, 1995; Trubiani et al, 1994; Selleri et al, 1995; Tarumi et al, 1995; Rodriguez-Villanueva and McDonnell, 1995; Berry et al, 1996; Wu et al, 1996).

In view of the powerful cytostatic and differentiative effects of IFN- $\gamma$ on several NB cell lines, we have investigated whether this cytokine is also able to modulate programmed cell death in these cellular models. By means of several validated techniques to detect apoptosis, we tested nine different NB cell lines for their sensitivity to IFN- $\gamma$-induced apoptosis. Apoptosis was found to occur following treatment with IFN- $\gamma$, although to a very variable degree between the cell lines. This effect did not require the continuous renewal of IFN- $\gamma$ in culture medium, and was indeed more evident if cells were treated only once without subsequent change of medium containing IFN $-\gamma$. Finally, it appeared that differentiation or apoptosis represent two mutually exclusive modalities of response to IFN- $\gamma$ at the single cell level, as determined by double labeling of cells with antibodies specific for differentiation markers and nuclear staining with propidium iodide.

\section{Results}

\section{Inhibition of in vitro growth and induction of differentiation of NB cell by IFN- $\gamma$}

The hallmarks of NB cell differentiation in vitro following treatment with IFN- $\gamma$ have been described in detail (Ponzoni et al, 1992). Although the changes observed vary broadly among the different cell lines and inducing treatments, the general features of NB cell differentiation include slowing or complete arrest of proliferation, loosening of cell clusters and emission of neuritic or dendritic processes. Moreover, a series of biochemical changes involving cytoskeletal proteins, membrane antigens and neurotransmitters biosynthetic pathways take place (Wuarin et al, 1991; Lanciotti et al, 1992). Inhibition of cell proliferation (Table 1) (with both cell count and tritiated thymidine incorporation), morphological changes and expression of mature cytoskeletal proteins were checked in the present study to assess cell differentiation, and, as expected, occurred to a different extent depending on the different cell lines (not shown). In four (LAN-5, ACN, SK-N-SH and SK-N-BE2C) of the nine cell lines the $I_{50}$ of IFN- $\gamma$ in inhibiting cell growth and triggering differentiation was $50-$ $100 \mathrm{IU} / \mathrm{ml}$. In the remaining cell lines (except GI-ME-N, which proved almost completely resistant) the $\mathrm{IC}_{50}$ was between 150 and $300 \mathrm{IU} / \mathrm{ml}$. IFN- $\gamma$ sensitivity in the different cell lines was (in decreasing order): $\mathrm{LAN}-5$ and $\mathrm{ACN}>>\mathrm{SK}-\mathrm{N}-\mathrm{SH}$ and SK-N-BE2C $>$ SK-N-BE2 $>$ IMR-32 and GI-LI-N $>$ GI-CA$\mathrm{N}>$ GI-ME-N.

\section{Induction of apoptosis by IFN- $\gamma$ in NB cells}

The data presented are from LAN-5 cells; similar results were obtained with the other cell lines (except GI-ME-N), but were less extensive and/or occurred later during the treatment.

\section{Quantitative determination of fragmented DNA labeling}

This assay measures the ratio between labeled DNA released into the culture medium and cytosol after internucleosomal fragmentation and total DNA labeling. Table 2 shows the results obtained following treatment of LAN-5 cells with $1000 \mathrm{IU} / \mathrm{ml} \mathrm{IFN}-\gamma$. Starting from $24-36 \mathrm{~h}$ after treatment, fragmented DNA labeling was consistently higher in treated than in control cells and, by $48 \mathrm{~h}$, about $20 \%$ of the label was found in released DNA (vs. $5 \%$ in controls). At subsequent times, if the culture was not refed with IFN- $\gamma$-containing medium, the percent of fragmented DNA released increased to up to 46 and $82 \%$ at days 3 and 5 , respectively (vs. correspondent control values of 8 and $13 \%$ ). When control or IFN- $\gamma$-containing medium was replaced at days 2 and 4 , the percentage of released DNA in IFN- $\gamma$-treated cells remained consistently higher than in control cells, but the difference was lower (25\% vs. $6 \%$ at day 5$)$ (not shown).

\section{Electrophoresis of DNA}

As illustrated in Figure 1, a considerable amount of DNA from IFN- $\gamma$-treated LAN-5 cells could be recovered as low molecular weight DNA as early as $24 \mathrm{~h}$ after treatment, with the characteristic 'laddering' of fragments of about $200 \mathrm{bp}$ and multiples thereof, typical of apoptotic cell death. This finding became more evident at $36 \mathrm{~h}$ and thereafter, consistent with results of tritiated thymidine DNA labeling (see above). This

Table 1 Phenotypic features, sensitivity to IFN- $\gamma$-induced growth arrest and IFN$\gamma$-receptor expression of the investigated NB cell lines

\begin{tabular}{|c|c|c|c|c|}
\hline \multirow[b]{2}{*}{ Cell lines } & \multirow[b]{2}{*}{ Phenotype $^{a}$} & \multirow[b]{2}{*}{$\begin{array}{l}I_{50}{ }^{b} \\
(I U / m I)\end{array}$} & \multicolumn{2}{|c|}{ IFN- $\gamma$-receptor } \\
\hline & & & $\begin{array}{l}\text { Binding } \\
\text { sites/cell }\end{array}$ & $\underset{\left(\times 10^{-10} \mathrm{M}\right)}{\mathrm{Kd}}$ \\
\hline LAN-5 & $\mathrm{N}$ & $55 \pm 7$ & $8098 \pm 1893$ & $3.6 \pm 1.9$ \\
\hline ACN & $\mathrm{S}$ & $51 \pm 4$ & $7327 \pm 1902$ & $4.8 \pm 1.1$ \\
\hline SK-N-SH & mixed $(\mathrm{N}, \mathrm{S}, \mathrm{I})$ & $89 \pm 4$ & $6932 \pm 1321$ & $4.1 \pm 1.2$ \\
\hline SK-N-BE2 & mixed $(\mathrm{N}, \mathrm{S}, \mathrm{I})$ & $182 \pm 15$ & $5140 \pm 1201$ & $3.8 \pm 1.2$ \\
\hline SK-N-BE2c & I & $83 \pm 6$ & $6450 \pm 1198$ & $29 . \pm 0.9$ \\
\hline IMR-32 & $\mathrm{N}$ & $211 \pm 16$ & $5621 \pm 988$ & $3.2 \pm 1.1$ \\
\hline GI-LI-N & $\mathrm{N}$ & $232 \pm 21$ & $6045 \pm 1125$ & $5.2 \pm 1.3$ \\
\hline GI-CA-N & mixed $(\mathrm{N}, \mathrm{S})$, & $295 \pm 27$ & $5961 \pm 1348$ & $4.2 \pm 1.6$ \\
\hline GI-ME-N & 1 & $>1 \overline{500}$ & $7423 \pm 1836$ & $4.9 \pm 1.4$ \\
\hline
\end{tabular}

${ }^{a} \mathrm{~N}$, neuroblastic; S, schwannian; I, intermediate. ${ }^{\mathrm{b}} \mathrm{C}_{50}$ was evaluated as doseresponse inhibition of ${ }^{3} \mathrm{H}$-thymidine incorporation and cell count. ${ }^{\mathrm{C}}$ Binding parameters were evaluated as described elsewhere (Montaldo et al., 1994).

Table 2 Time-dependent effect of IFN- $\gamma$ on LAN-5 cell death evaluated by $\left[{ }^{3} \mathrm{H}\right]$-thymidine labelling of fragmented DNA

\begin{tabular}{|c|c|c|c|c|c|c|c|}
\hline \multirow[b]{2}{*}{ Times in culture (h) } & \multicolumn{7}{|c|}{$\%$ of apoptotic cells ${ }^{a}$} \\
\hline & 6 & 12 & 24 & 36 & 48 & 72 & 120 \\
\hline $\begin{array}{l}\text { Control cells } \\
\text { IFN- } \gamma(1000 \mathrm{IU} / \mathrm{ml})\end{array}$ & $\begin{array}{l}7 \pm 1 \\
6 \pm 2\end{array}$ & $\begin{array}{c}5 \pm 2 \\
7.5 \pm 1.5\end{array}$ & $\begin{array}{c}4 \pm 3 \\
9.5 \pm 2.5\end{array}$ & $\begin{array}{c}6 \pm 2.5 \\
15 \pm 3.5\end{array}$ & $\begin{array}{l}4.5 \pm 2 \\
22 \pm 4\end{array}$ & $\begin{array}{l}8.5 \pm 3 \\
46 \pm 5\end{array}$ & $\begin{array}{c}13 \pm 5 \\
82 \pm 10\end{array}$ \\
\hline
\end{tabular}

a Data are the mean \pm S.D. of five independent experiments, each done in triplicate. 
observation was much less evident in control cells, in which faint initial aspects of DNA fragmentation appear only after $60 \mathrm{~h}$ of culture without changing the medium and likely reflect some degree of cell death due to consumption of growth or survival factors.

\section{Morphologic evaluation of apoptosis}

Programmed cell death was assessed by fluorescence microscopy of the cells after PI staining. After $48 \mathrm{~h}$ of IFN- $\gamma$ treatment, several LAN-5 cells displayed bright nuclear staining and highly condensed nuclei. In many cells, chromatin was aggregated in dense masses at the periphery of the nucleus and, in some cases, fragmented (Figure 2b). In control cells these features were observed only occasionally and were less evident (Figure 2a). Ultrastructural analysis by electron microscopy confirmed the above findings, showing a progressive condensation of cytoplasm and nuclear chroma-

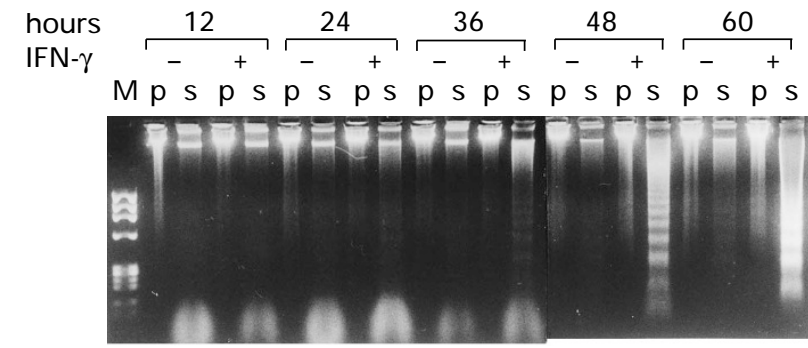

Figure 1 IFN- $\gamma$-induced DNA fragmentation in LAN-5 cells. Approximately $1 \times 10^{6}$ untreated $(-)$ or IFN- $\gamma$-treated $(+)$ cells per point were lysed and the DNA was extracted and subjected to electrophoresis as described in Materials and methods. $\mathrm{p}=$ pellets; $\mathrm{s}=$ supernatants. $\mathrm{M}=\mathrm{Hae}$ III-digested $\phi_{\chi}$ DNA providing molecular size markers.
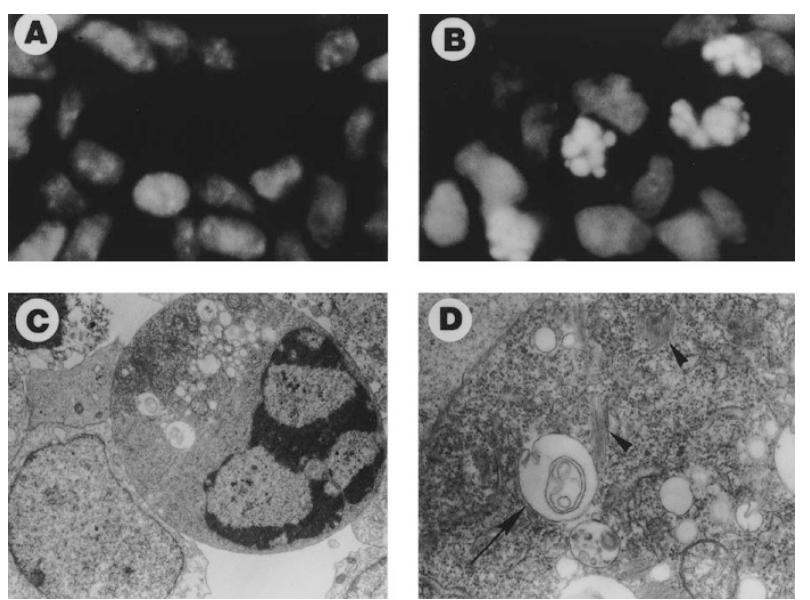

Figure 2 Morphological assessment of programmed cell death in LAN-5 cells with PI staining and fluorescent microscopy (A and $\mathbf{B}$ ) and electron microscopy (C and D). Cells were left untreated $(\mathbf{A})$ or treated for $48 \mathrm{~h}$ with $1000 \mathrm{IU} / \mathrm{ml}$ of IFN $-\gamma$ (B, C and D). In B nuclear condensation and partial fragmentation can be seen in some cells. C: ultrastructural appearance of a cell undergoing apoptosis. Chromatin is condensed underneath the nuclear membrane. Organelles segregate in a distinct cytoplasmic area. Mitochondia show loss of cristae and degeneration. For comparison a normal cell is shown in the bottom left corner. $\mathbf{D}$ : higher magnification of $\mathbf{C}$ showing a cytoplasmic area containing vacuoles (arrow), mitochondrial degeneration and bundles of microfilaments (arrowheads). Original magnification: A and b $630 \times$; C $4400 \times$; D $20000 \times$ tin, which tended to aggregate underneath the nuclear envelope. Moreover, compartimentalization of organelles to a discrete cytoplasmic area (probably as a consequence of cytoskeletal disorganization), various degrees of mitochondrial degeneration, appearance of cytoplasmic vacuoli and the formation of microfilament bundles within the cytoplasm were observed (Figure 2c and d).

Interestingly, these morphologic aspects of apoptosis were synchronous, with cells in the same stage of the apoptotic process being present in the sample. The above features became more prominent at later times in culture, particularly in IFN- $\gamma$-treated cells whose medium was not renewed.

Cytofluorimetric analysis DNA content of NB cells was assessed by PI staining and flow cytometric analysis (Figure 3 ). We observed an increase in the number of hypodiploid (apoptotic) cells, which was statistically significant as early as $36 \mathrm{~h}$ after treatment with IFN- $\gamma(8.2 \%$ vs. $1.3 \%$ in controls, $P<0.05$ by two tailed Student's $t$ test) (panels a and $b$ ). This pattern became more evident with time (c). At later time points, a sharp difference was observed between cells whose medium $( \pm \mathrm{IFN}-\gamma)$ was changed every other day of culture (panels $f$ and i) and those that were left in the same medium (panels e and $h$ ). In the first case, the rate of apoptotic cells in treated cultures was about $6 \%$ (vs. $1.5 \%$ in controls) at $72 \mathrm{~h}$ and about $13 \%$ (vs. $2 \%$ ) by day 5 . Conversely, in cells which did not receive fresh medium, the rate of apoptosis was more pronounced in IFN- $\gamma$-treated cells, with $34 \%$ of apoptotichypodiploid cells at $72 \mathrm{~h}$ (vs. control value of $4 \%$ ) and $56 \%$ by day 5 (vs. 9\%).

\section{Immunofluorescence and PI staining}

To better assess whether the characteristic aspects of differentiation and apoptosis involved the same cells or two different cell subpopulations, NB cells were treated or not with IFN- $\gamma$, incubated with $\mathrm{mAbs}$ specific for 'mature' cytoskeletal proteins and counter-stained with the DNA-marking agent PI. Figure 4 shows the results of these experiments in LAN-5 cells probed with mAbs directed toward $200 \mathrm{kDa} N F$ (NF200), their phosphorylated form (NF-200-P) and MAP-5. The data at 5 days are representative of cells refed with fresh medium every other day, since the high rate of mortality in IFN- $\gamma$-treated cells did not allow the recovery of a sufficient number of cells for microscopic evaluation when culture medium was not changed for 5 days. As shown in the Figure, cytoskeletal markers were already present in control cells in a diffuse and unlocalized pattern. Following treatment with IFN$\gamma$, these proteins tended to organize themselves in a more defined structure and, eventually, they sharply depict the perikarya, the cytoplasmic extensions and the growth cones, while leaving the nuclei well distinct. Characteristically, cells showing this kind of organization do not show evidence of chromatin condensation and nuclear fragmentation and maintain a diffuse and weak pattern of nuclear PI staining. Conversely, these cytoskeletal changes cannot be observed in cells undergoing apoptosis, whose nuclei appear brightly stained by $\mathrm{PI}$ and frequently fragmented, and whose cytoskeleton is only weakly or not at all distinguishable. Interestingly, in agreement with the data from DNA 


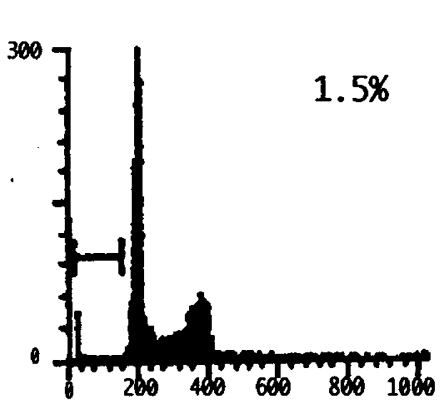

A

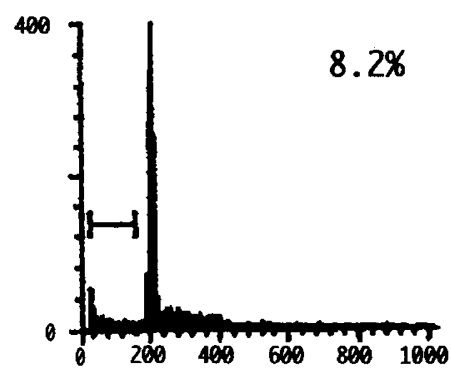

B

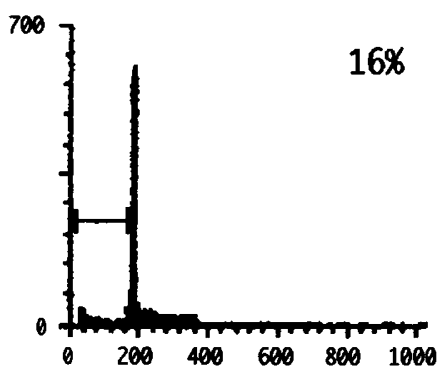

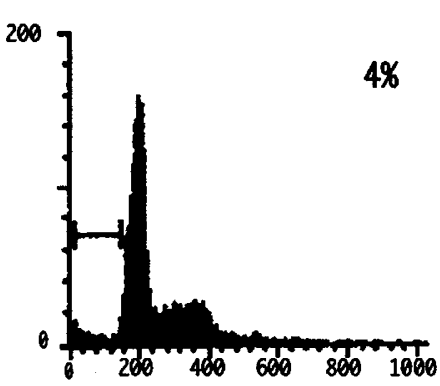

D

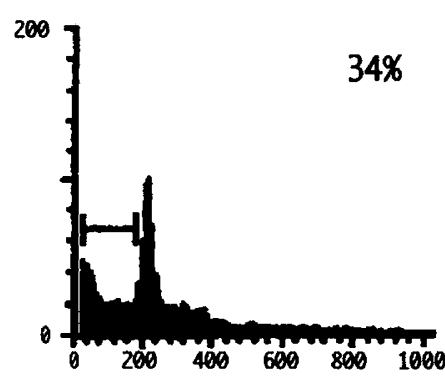

E

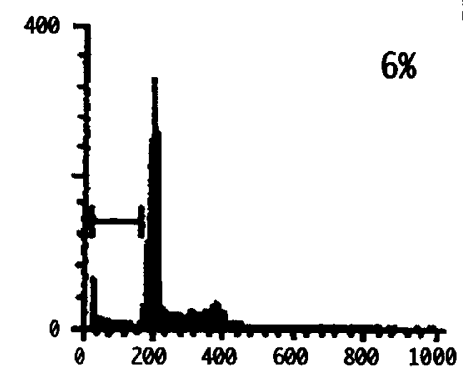

F

C

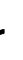

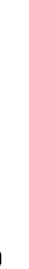

F 
NF-200

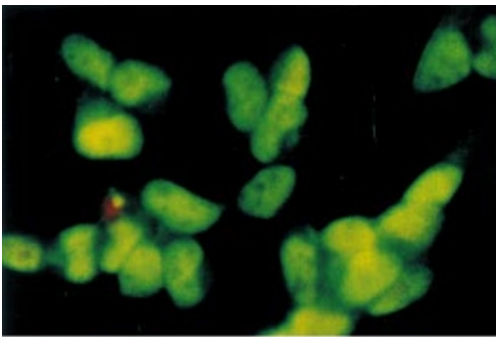

CTR

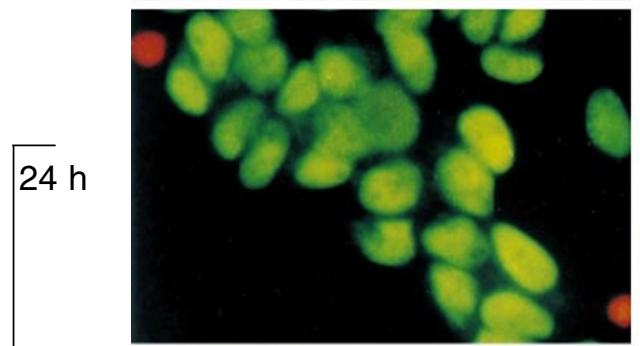

$48 \mathrm{~h}$
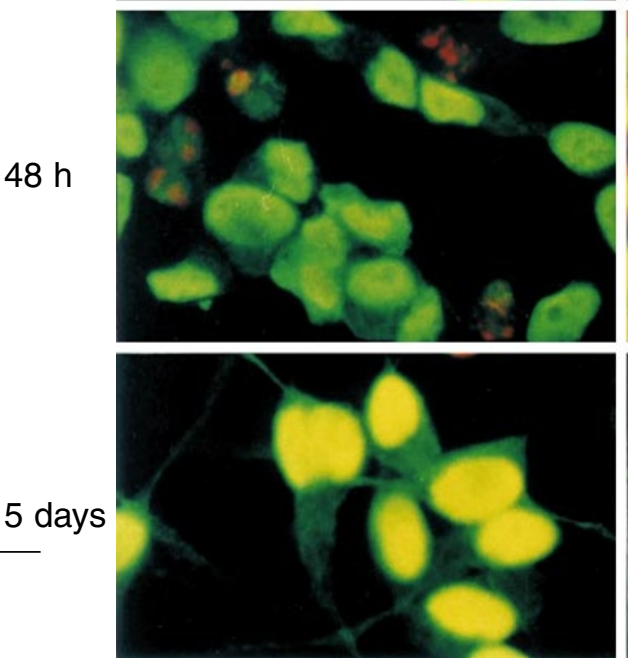

NF-200-P
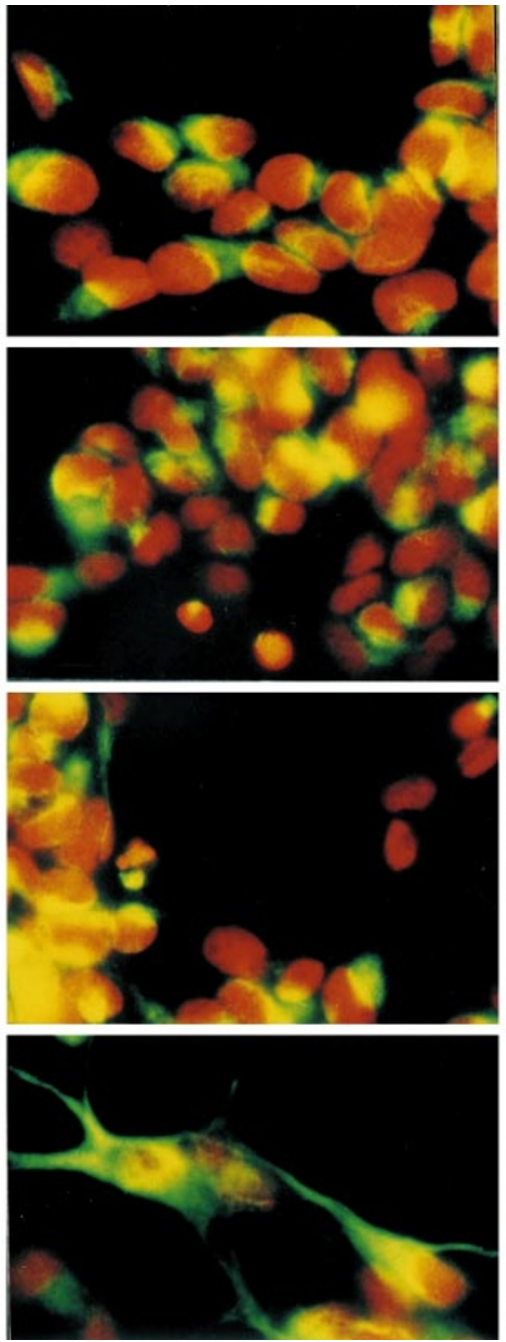

MAP-5
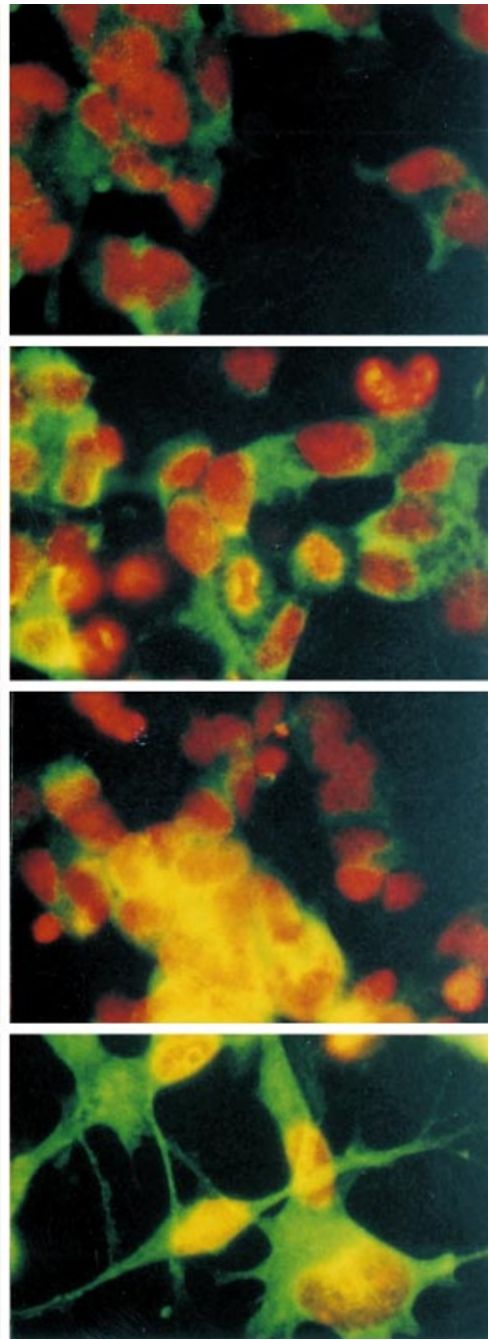

Figure 4 Fluorescence microscopy of untreated (CTR) or IFN- $\gamma$-treated (IFN- $\gamma$ ) LAN-5 cells after staining with PI and mAbs specific to NF 200, NF 200-P and MAP 5. The cells examined at 5 days $(120 \mathrm{~h}$ ) have been refed twice with control or IFN- $\gamma$-containing medium. Note the prevalence of apoptotic over differentiated appearance of the cells up to $48 \mathrm{~h}$, a time at which no change of culture medium was performed. At day 5 , after two medium changes, the differentiated phenotype prevails over apoptosis in IFN- $\gamma$-treated cells.

counterpart of this in vivo phenomenon may be represented by the relative ease with which some established NB cell lines can be induced to undergo differentiation following treatment with a variety of chemical compounds such as cAMP or its analogues, natural or chemically-derived morphogens, such as Retinoic Acid, or naturally secreted cytokines such IFN- $\gamma$ and Tumor Necrosis Factor (TNF) (Pahlman et al, 1981; Sidell, 1982; Rupniak et al, 1984; Abemayor and Sidell, 1989; Parodi et al, 1989; Perez-Polo et al, 1989; Wuarin et al, 1991; Ponzoni et al, 1992). Unfortunately, however, resistance to the differentiation-promoting activity of these compounds is often encountered.

Among the natural agents reportedly able to promote phenotypic maturation of NB cells in vitro, IFN- $\gamma$ and, particularly, its combination with TNF have proven very promising (Ponzoni et al, 1992). IFN- $\gamma$-induced differentiation of NB cells has been studied extensively by us and others and its biological, biochemical and phenotypic features have been described in detail (Wuarin et al, 1991; Ponzoni et al, 1992; Lanciotti et al, 1992). On the other hand, it has been reported that both type I and II interferons exert a prominent role in controlling, either positively or negatively, the process of programmed cell death in a variety of biological models, including hematopoietic cells, $T$ and B lymphocytes and epithelial cells (Trubiani et al, 1994; Lotem and Sachs, 1995; Selleri et al, 1995; Tarumi et al, 1995; Rodriguez-Villanueva and McDonnell, 1995; Berry et al, 1996; Wu et al, 1996). We thus decided to explore the 
possibility that, besides differentiation, IFN $-\gamma$ could also regulate apoptosis in NB cells.

To this purpose we used nine NB cell lines, endowed with different phenotypic characteristics and with a very broad spectrum of sensitivity to the differentiation-promoting activity of IFN- $\gamma$. The cells were either treated once and subsequently cultured for 5 days without further change of the medium, or refed with fresh medium (with or without IFN- $\gamma$ ) every other day. The former condition mimics a partial and progressive serum starvation, and was chosen owing to the extremely high rate of spontaneous cell death observed in preliminary experiments in which serum was totally omitted in culture medium.

The typical pattern of apoptotic cell death could be observed in a time- and culture condition-dependent manner following treatment with IFN- $\gamma$, although with different intensity and time kinetics between the cell lines. Specifically, the first signs of apoptosis were already evident in the most sensitive cell lines (LAN-5 and ACN) after 24-36 $\mathrm{h}$ of treatment, the same times at which slight reduction of the proliferation rate and early morphologic changes indicative of ongoing differentiation take place. By $48 \mathrm{~h}$, both maturational aspects and apoptotic features were frankly evident in the same culture. Thus, it appears that cellular differentiation and programmed cell death are triggered and evolve simultaneously in NB cells following stimulation of IFN- $\gamma$ receptor. Interestingly, double labeling of cells with cytoskeletal-specific mAbs and PI nuclear staining, revealed that the two processes are mutually exclusive at the single cell level, suggesting that differences in the metabolic and/or cell cycle state can influence the cellular fate. After $48 \mathrm{~h}$, a sharp prevalence of one cellular program over the other seems to depend strongly upon the renewal of culture medium and, presumably, the growth or survival factors therein. If cell cultures were left untreated, apoptosis was prominent and, according to thymidine labeling of fragmented DNA, involved almost $80 \%$ of the cells by day 5 (56\% with cytofluorimetric analysis of DNA content). Conversely, if cultures were refed with new medium, in the presence of IFN- $\gamma$, cellular differentiation was prevalent, though the apoptotic rate in treated cells was still significantly higher than in control cultures. This finding is reminiscent of that observed by Novelli et al, 1994, who found that culturing malignant $T$ cell lines in serum free medium increased their susceptibility to IFN- $\gamma$ induced apoptosis, while in serum containing medium IFN- $\gamma$ promoted mainly the proliferation and differentiation of these cells (Novelli et al, 1994). A similar situation has also been reported for experimental models of hematopoiesis, in which both type I and type II IFNs provoked apoptotic cell death of progenitor cells which was partially counteracted by addition of hematopoietic growth factors (Selleri et al, 1995; Tarumi et al, 1995). Thus, a general mechanism whereby IFN- $\gamma$ triggers programmed cell death seems to involve an increased factor-dependence of target cells. In this regard, it is noteworthy that from preliminary experiments in our laboratory, both IGF I and II and, to a lesser extent, insulin, proved able to dose-dependently rescue serum-starved NB cells from IFN- $\gamma$-induced cell death (PGM and MP, personal observation).
As already outlined, the different cell lines used showed a very broad spectrum of ability to acquire a differentiated phenotype following IFN- $\gamma$ treatment. As far as IFN- $\gamma$ induced apoptosis is considered, we found that sensitivity of the various NB cell lines paralleled their differentiative response. This finding cannot be accounted for by different levels of expression of IFN- $\gamma$-receptor, since in binding experiments all these cell lines exhibited comparable amounts of specific IFN- $\gamma$-binding with similar dissociation constants (Table 1); these binding parameters were comparable with those already described in NB-unrelated models (van Loon et al, 1991). Thus, it is conceivable that responsiveness to IFN- $\gamma$, either in terms of differentiation or apoptotis, is mediated by some other factor downstream of receptor activation. A hypothetical factor involved in the different IFN- $\gamma$ sensitivities could be represented by the divergent constitutive phenotype (i.e. neuroblastic, schwannian or intermediate) of the cell lines. To address this point, we used a panel of nine NB cell lines, broadly including all the phenotypic characteristics from frankly neuroblastic $(N$, i.e. LAN-5, GI-LI-N and IMR-32), to schwann-like (S, i.e. $A C N$ ), covering intermediate (I, i.e. SK-N-BE2c) features. From our results, we could exclude a relationship between cellular phenotype and IFN- $\gamma$ sensitivity, as the two most sensitive cell lines, LAN-5 and ACN, belonged to the two opposite cell types (ACN cells indeed express a considerable amount of the schwannian marker S-100, which is strikingly increased by IFN- $\gamma$ treatment, as detected by immunohistochemistry, not shown).

The mechanism(s) whereby IFN- $\gamma$ induces apoptosis is still to be elucidated. Recently, Tanaka et al. have identified an IFN-inducible transcription factor, IRF-1, whose expression in ras-transformed embryonic fibroblasts cultured in low serum conditions caused these cells to undergo apoptotic cell death; these Authors also showed that, in the same conditions, cells derived from mice carrying a null mutation in the IRF-1 gene (IRF-1 ${ }^{-1-}$ mice) did not die (Tanaka et al, 1994). The role of IRF-1 in IFN- $\gamma$-induced apoptosis is further supported by Tamura et al (1995), who showed that radiation- and cytostatic drug-induced apoptosis in activated T lymphocytes is strictly dependent upon expression of a functional IRF-1 gene and did not take place in $\mathrm{IRF}-1^{-I}$ cells. Interestingly, these Authors demonstrated that IRF-1 is a direct and powerful transactivator of the Interleukin-1 $\beta$ converting enzyme (ICE) gene, the mammalian homologue of the Caenorhabditis Elegans cell death gene ced-3. ICE is considered to exert a prominent role in determining apoptosis in mammalian cells (Miura et al, 1993). Although preliminary experiments in our laboratory do not indicate an increase in ICE gene expression following IFN- $\gamma$ treatment of NB cells, a considerable induction of the closely ICE-related apopain gene (Nicholson et al, 1995) was observed and the possible role of IRF-1 in this effect is under investigation (MP, unpublished data). Whatever the biochemical pathway involved, it is now evident that IFNs are potent molecules delivering apoptotic signals to their target cells. As to NB cells, there appears to exist a dual modality of response to IFN- $\gamma$, though the checkpoint at which the decision is made whether to differentiate or undertake cell death remains 
obscure. It may be hypothesised, from our experiments, that the availability of serum survival/growth factors is involved in determining the cellular fate.

\section{Materials and Methods}

\section{Chemicals and reagents}

Recombinant human IFN- $\gamma$ was a generous gift from Boehringer (Vienna, Austria). Monoclonal antibodies directed to neuronal differentiation markers with the following specificities: phosphorylated and non-phosphorylated $200 \mathrm{KDa}$ neurofilaments (NF); Microtubuleassociated proteins (MAP)-2, MAP-5 and MAP- $\tau$ (low molecular weight MAPs) were purchased from Sigma Chemicals (St. Louis, MO).

\section{Cell lines and culture conditions}

To cover the broadly variable phenotype of NB cells, nine human NB cell lines were used: LAN-5 (Seeger et al, 1982), SK-N-SH (Biedler et al, 1973), SK-N-BE2 and its subclone SK-N-BE2c (Biedler et al, 1978), IMR-32 (Tumilowicz et al, 1970), ACN (Gross et al, 1989), GI-LI-N (Longo et al, 1988), GI-CA-N (Cornaglia Ferraris et al, 1990a) and GlME-N (Cornaglia Ferraris et al, 1990b) (see Table 1). Cells were maintained in the logarithmic phase of growth in $75 \mathrm{~cm}^{2}$ plastic culture flasks (Corning, Bibby Sterilin Ltd., Staffordshire, UK) in RPMI 1640 medium (Biochrom, Berlin, Germany) supplemented with $15 \%$ heatinactivated foetal calf serum (FCS) (Biochrom), sodium penicillin G (50 IU/ml), and streptomycin sulfate $(50 \mu \mathrm{g} / \mathrm{ml})$ (complete medium) at $37^{\circ} \mathrm{C}$ in a $5 \% \mathrm{CO}_{2}-95 \%$ air humidified incubator. Cells were split following treatment with $1 \mathrm{mM}$ EDTA in Hank's salts solution (Flow Laboratories, Milan, Italy), washed, counted, and replated in fresh complete medium. For the experiments, the cells were treated with IFN- $\gamma(1000 \mathrm{IU} / \mathrm{ml})$ or control complete medium, and then the cultures were left for 5 days or, alternatively, refed every other day with fresh medium without (controls) or with IFN- $\gamma$ up to day 5 ; in these latter experiments, detached, floating cells were collected by centrifugation and reseeded in cultures at the moment of changing the medium and evaluated together with adherent cells.

\section{Cell morphology}

The cells were seeded into T-25 flasks with $5 \mathrm{ml}$ of culture medium and treated with IFN- $\gamma$ as described above. From day 1 of treatment, 200 cells/culture from at least three different random areas of the flasks were examined daily with a phase contrast microscope (Olympus IMT2). Detection of apoptotic nuclei was performed according to Jacobson et al, (1993). Briefly, after the treatment period, the cells were fixed in $4 \%$ paraformaldehyde in $0.1 \mathrm{M}$ phosphate buffer, $\mathrm{pH} 7.4$ for 10 min at room temperature, followed by a 10 min incubation with $5 \%$ acetic acid, $95 \%$ ethanol at $-20{ }^{\circ} \mathrm{C}$, and then stained with propidium iodide (PI, ICN, Costa Mesa, Ca) $[0.05 \mu \mathrm{g} / \mathrm{ml}$ in phosphate buffered saline (PBS) containing $50 \mu \mathrm{g} / \mathrm{ml}$ RNase A (ICN) for $30 \mathrm{~min}$ at $37^{\circ} \mathrm{C}$. The cells were mounted in permanent aqueous mounting medium (Ortho Diagnostic Systems, Milan, Italy) and examined with a Leitz Orthoplan fluorescence microscope (Leitz, Wetzlar, Germany).

For electron microscopy, after detaching and washing, the cells were fixed with $2.5 \%$ glutaraldehyde (Merck, Darmstadt, Germany) in $0.1 \mathrm{M}$ cacodylate buffer (pH 7.4), post-fixed with $1 \% \quad \mathrm{OsO}_{4}$ (Polysciences, Warrington, PA) in 0.1 cacodylate buffer, stained with uranyl acetate, dehydrated and embedded in Araldite (Serva, Heidelberg, Germany). Ultrathin sections were collected on grids, stained with uranyl acetate and lead citrate and observed with a Zeiss EM 109 electron microscope.

\section{Assay for inhibition of cell growth}

NB cells were plated into T-25 flasks and treated as described. At different time points, the cells were detached with EDTA solution and counted with a hematocytometer, using a Turk dye solution. To assess $\left[{ }^{3} \mathrm{H}\right]$ thymidine incorporation NB cells were plated in sixtuplicate wells of flat-bottomed 96-well microtest plates (Costar, Cambridge, MA). At various intervals after adding IFN- $\gamma$, the plates were pulsed with $0.5 \mu \mathrm{Ci}$ [methyl ${ }^{3} \mathrm{H}$ ]thymidine/well (specific activity $5 \mathrm{Ci} / \mathrm{mmol}$; Amersham, Buckinghamshire, UK), incubated for $18 \mathrm{~h}$ at $37^{\circ} \mathrm{C}$, trysinized and the radioactivity associated with individual samples was measured in a liquid scintillation counter (Tri-Carb 4530; Packard Instruments Company, Downers Grove, IL).

\section{Microscopic immunofluorescence analysis and double labelling}

Cytoskeletal proteins were detected as previously reported (Ponzoni et al, 1992), using mAbs with the following specificities: $\mathrm{M}_{\mathrm{r}}$ 200.000 NF and their phosphorylated form, MAP2, MAP5 and $\operatorname{MAP}(\tau)$. Briefly, the cells were seeded into multiwell slides (Nunc, Naperville, IL) and incubated as described. At the defined times the slides were permeabilized in $4 \%$ paraformaldehyde in sodium phosphate $0.1 \mathrm{M}(\mathrm{pH} 7.4)$ for $10 \mathrm{~min}$ at R.T. and fixed with $5 \%$ acetic acid in absolute ethanol for $10 \mathrm{~min}$ at $-20^{\circ} \mathrm{C}$. The slides were then saturated for $20 \mathrm{~min}$ at R.T. with normal goat serum and incubated for $1 \mathrm{~h}$ at $37^{\circ} \mathrm{C}$ in a humid chamber with $200 \mu \mathrm{l}$ of the appropriately diluted mAbs. After three washings with PBS, a second incubation (45 min at $4^{\circ} \mathrm{C}$ ) with fluorescein isothiocianate-conjugated goat anti-mouse immunoglobulin (Sigma) was performed. The cells were washed twice, observed under a fluorescence microscope (Leitz Orthoplan) and evaluated as described elsewhere (Ponzoni et al, 1988). For experiments in which both nuclear $\mathrm{PI}$ staining and cytoskeletal markers were evaluated simultaneously (double labeling), the cells were incubated as above for cytoskeletal markers. After that, a solution containing $0.05 \mu \mathrm{g} / \mathrm{ml}$ of PI and $50 \mu \mathrm{g} / \mathrm{ml}$ RNase A in PBS was added for $30 \mathrm{~min}$ in the dark at $37^{\circ} \mathrm{C}$. After washing in PBS, the slides were mounted in Citifluor (Citifluor Ltd., London, UK) and examined as above.

\section{Quantitative evaluation of apoptosis}

The percentage of apoptotic cells was evaluated by a modification of the JAM test (Matzinger, 1991) and of the quantitative assay described by Wright et al. (1992). Briefly, NB cells were treated or not with IFN- $\gamma$, as described, in 24 well tissue culture plates. During the last $16 \mathrm{~h}$ the cells were labeled with $\left[{ }^{3} \mathrm{H}\right]$ thymidine (specific activity $100 \mathrm{Ci} / \mathrm{mmole} ; 5 \mu \mathrm{Ci} / 1 \times 10^{6}$ cells). After removal of medium, the cells were rinsed three times with complete medium and then complete medium $( \pm \mathrm{IFN}-\gamma)$ was added for a further $6 \mathrm{~h}$. At the end of the incubation, supernatants were removed for scintillation counting and the cells were lysed by the addition of $0.5 \mathrm{ml}$ of lysis buffer (10 M Tris- $\mathrm{HCl}$, pH 7.5, 1 mM EDTA, 0.2\% Triton X-100). Intact chromatin was separated from fragmented DNA by centrifugation at $13.000 \mathrm{~g}$ for $20 \mathrm{~min}$. The pellets were resuspended in $0.5 \mathrm{ml}$ of $1 \%$ sodium dodecyl sulfate. Both lysates and pellets were then counted in a scintillation counter. Percent DNA fragmentation was calculated as follows:

$\%$ DNA release $=$

cpm supernatant $+\mathrm{cpm}$ lysate $\overline{\mathrm{cpm} \text { supernatant }+\mathrm{cpm} \text { lysate }+\mathrm{cpm} \text { pellet }} \times 100$ 


\section{Flow cytometry}

Detection of apoptotic/hypodiploid cells was performed using a modification of the technique described by Nicoletti et al. (1991). Briefly, aliquots of $1 \times 10^{6}$ cells were centrifuged at $1200 \mathrm{rpm}$ for $10 \mathrm{~min}$, and the pellets were fixed with $70 \%$ ethanol overnight. The cells were washed twice with PBS and then resuspended in $1 \mathrm{ml}$ of a solution containing $3.4 \mathrm{mM}$ sodium citrate, $20 \mu \mathrm{g} / \mathrm{ml} \mathrm{PI}, 100 \mu \mathrm{g} / \mathrm{ml}$ RNase $A$ and stored in the dark for 30 min. Cells were analyzed on a FACScan flow cytometer (Becton-Dickinson, Mountain View, CA). At least 10000 events were acquired for each sample.

\section{DNA fragmentation assay}

Cells were treated as described, washed with ice-cold PBS, centrifuged at $1200 \mathrm{rpm}$ for $10 \mathrm{~min}$, and resuspended in lysis buffer consisting of $10 \mathrm{mM}$ Tris- $\mathrm{HCl}(\mathrm{pH} 8.0), 1 \mathrm{mM}$ EDTA, $0.2 \%$ Triton $\mathrm{X}$ 100. Cell lysis was carried out for $5 \mathrm{~min}$ at $4^{\circ} \mathrm{C}$ after briefly vortexing. Cell lysates were then centrifuged at $13000 \mathrm{rpm}$ for $30 \mathrm{~min}$ at $4^{\circ} \mathrm{C}$. Supernatants (S) were treated with $100 \mu \mathrm{g} / \mathrm{ml}$ proteinase K (Sigma) and incubated overnight (o.n.) at $37^{\circ} \mathrm{C}$. Pellets $(P)$ were resuspended in $10 \mathrm{mM}$ Tris- $\mathrm{HCl}$ (pH 8.0), $1 \mathrm{mM}$ EDTA, $0.5 \%$ SDS, $100 \mu \mathrm{g} / \mathrm{ml}$ Proteinase $\mathrm{K}$ and incubated o.n. at $37^{\circ} \mathrm{C}$. Both $\mathrm{S}$ and $\mathrm{P}$ were Phenol/ Chloroform extracted, then precipitated overnight at $-20^{\circ} \mathrm{C}$ by adding $1: 100(\mathrm{v} / \mathrm{v}) 1 \mathrm{M} \mathrm{MgCl}_{2} 1: 10(\mathrm{v} / \mathrm{v}) 3 \mathrm{M} \mathrm{Na}$ acetate $(\mathrm{pH} 5.2)$ and $1 \mathrm{vol}$ of isopropyl alcohol. DNA was then pelletted by centrifugation at $13000 \mathrm{rpm}$ for $20 \mathrm{~min}$, washed with $1 \mathrm{vol}$ of $70 \%$ ethanol and dried under vacuum. DNA was resuspended in $10 \mathrm{mM}$ Tris- $\mathrm{HCl}(\mathrm{pH} 8.0)$, $1 \mathrm{mM}$ EDTA buffer supplemented with $50 \mu \mathrm{g} / \mathrm{ml}$ RNase A and incubated for $2 \mathrm{~h}$ at $37^{\circ} \mathrm{C}$. Samples were then analyzed on $1.2 \%$ agarose gel electrophoresis, in $40 \mathrm{mM}$ Tris-acetate, $1 \mathrm{mM}$ EDTA (TAE) buffer ( $\mathrm{pH}$ 8.0). One $\mu \mathrm{g}$ of Haelll-digested $\phi_{\chi}$ DNA (Pharmacia Biotech, Uppsala, Sweden) was applied to each gel to provide molecular size markers. DNA banding was visualized with a UV transilluminator.

\section{${ }^{125}$ I-IFN- $\gamma$ binding assay}

Analysis of binding parameters was carried out as described (Montaldo et al, 1994).

\section{Acknowledgements}

The Authors thank Dr. GR Adolf (Boehringer, Vienna) for kindly providing human recombinant IFN- $\gamma$ and Dr. V Pistoia and Dr. MV Corrias for critically reviewing the manuscript. LR is a recipient of an AIRC (Italian Association for Cancer Research) award. This work was partially supported by AIRC and by Ricerca Corrente Ministeriale Gaslini.

\section{References}

Abemayor E and Sidell N (1989) Human neuroblastoma cell lines as models for the in vitro study of neoplastic and neuronal cell differentiation. Environ. Health Perspect. 80: 3-15

Ambros IM, Zellner A, Roald B, Amann G, Ladenstein R, Printz D, Gadner H and Ambros PF (1996) Role of ploidy, chromosome 1p, and Schwann cells in the maturation of neuroblastoma. New Engl. J. Med. 334: 1505-1511

Berry DE, Lu YM, Schmidt B, Fallon PG, O'Connell C, Hu SX, Xu HJ and Blanck G (1996) Retinoblastoma protein inhibits IFN-gamma induced apoptosis. Oncogene. 12: 1809-1819

Biedler JL, Helson L and Spengler BA (1973) Morphology and growth, tumorigenicity, and cytogenetics of human neuroblastoma cells in continuous culture. Cancer Res. 33: 2643-2652
Biedler JL, Roffer-Tarlov S, Schachner M and Freedman LS (1978) Multiple neurotransmitter synthesis by human neuroblastoma cell lines and clones. Cancer Res. 38: 3751-3757

Cornaglia-Ferraris P, Ponzoni M, Montaldo P, Mariottini GL, Donti E, Di Martino D and Tonini G (1990a) A new human highly tumorigenic neuroblastoma cell line with undetectable expression of $\mathrm{N}$-myc. Pediat. Res. 27: 1-6

Cornaglia-Ferraris P, Sansone R, Mariottini GL, Longo L and Tonini G (1990b) Evidence of loss of $\mathrm{N}$-myc amplification during the establishment of a human neuroblastoma cell line. Int. J. Cancer. 45: 578-579

D'Angio GJ, Evans AE and Koop CE (1971) Special pattern of widespread neuroblastoma with a favorable prognosis. Lancet. 1: 1046-1049

Dive C and Hickman JA (1991) Drug-target interactions: only the first step in the commitment to a programmed cell death? Br. J. Cancer. 64: 192-196

Garaventa A, Rondelli R, Lanino E, Dallorso S, Dini G, Bonetti F, Arrighini A, Santoro N, Rossetti F, Miniero R, Andolina M, Amici A, Indolfi P, Lo Curto M, Favre C, Paolucci P, Pession A and De Bernardi B for the Italian Association of Pediatric Hematology-Oncology, BMT Group (1996) Myeloablative therapy and bone marrow rescue in advanced neuroblastoma. Reportfrom the Italian Bone Marrow Transplant Registry. Bone Marrow Transpl., in press

Gross N, Beck D, Portoukalian J, Favre S and Carrel S (1989) New anti-GD2 monoclonal antibodies produced from gamma-interferon-treated neuroblastoma cells. Int. J. Cancer. 43: 665-671

Haas D, Ablin AR, Miller C, Zoger S and Matthay KK (1988) Complete pathologic maturation and regression of stage IV-S neuroblastoma without treatment Cancer: 62: 818-825

Hanada M, Krajewski S, Tanaka S, Cazals-Hatem D, Spengler BA, Ross RA, Biedler JL and Reed JC (1993) Regulation of Bcl-2 oncoprotein levels with differentiation of human neuroblastoma cells. Cancer Res. 53: 4978-4986

Jacobson MD, Burne JF, King MP, Miyashita T, Reed J and Raff MC (1993) Bcl-2 blocks apoptosis in cells lacking mitochondrial DNA. Nature. 361: 365-369

Lanciotti M, Montaldo PG, Folghera S, Lucarelli E, Cornaglia-Ferraris P and Ponzoni M (1992) A combined evaluation of biochemical and morphological changes during human neuroblastoma cell differentiation. Cell. Mol. Neurobiol. 12: 225240

Longo L, Christiansen $\mathrm{H}$, Christiansen NM, Paulsen $\mathrm{P}$, Cornaglia-Ferraris $\mathrm{P}$ and Lampert $F$ (1988) N-myc amplification at chromosome band 1 p32 in neuroblastoma cells as investigated by in situ hybridization. J. Cancer Res. Clin. Oncol. 114: 636-640

Lotem J and Sachs L. (1995) Interferon- $\gamma$ inhibits apoptosis induced by wild-type p53, cytotoxic anti-cancer agents and viability factor deprivation in myeloid cells. Leukemia. 9: 685-692

Lowe SW, Ruley HE, Jacks T and Housman DE (1993) p53-dependent apoptosis modulates the cytotoxicity of anticancer agents. Cell. 74: 957-967

Marx J (1993) Cell death studies yield cancer clues. Science. 259: 760-761

Matzinger P (1991) The JAM test: a simple assay for DNA fragmentation and cell death. J. Immunol. Meth. 145: 185-188

Melino G, Annicchiarico-Petruzzelli M, Piredda L, Candi E, Gentile V, Davies PJA and Piacentini M (1994): Tissue transglutaminase and apoptosis: sense and antisense transfection studies with human neuroblastoma cells. Mol. Cell. Biol. 14: $6584-6596$

Miura M, Zhu H, Rotello R, Hartwieg EA and Yuan J (1993) Induction of apoptosis in fibroblasts by IL-1 $\beta$-converting enzyme, a mammalian homolog of the $C$. Elegans cell death gene ced-3. Cell. 75: 653-660

Montaldo PG, Carbone R, Corrias MV, Cornaglia-Ferraris P and Ponzoni M (1994) Synergistic differentiation-promoting activity of interferon $\gamma$ and tumor necrosis factor- $\alpha$ : Role of receptor regulation on human neuroblasts. J. Natl. Cancer Inst. 86: $1694-1701$

Nicholson DW, Ali A, Thornberry NA, Vaillancourt JP, Ding CK, Gallant M, Gareau Y, Griffin PR, Labelle M, Lazebnik YA, Munday NA, Raju SM, Smulson ME, Yamin TT, Yu VL and Miller DK (1995) Identification and inhibition of the ICE/CED-3 protease necessary for mammalian apoptosis. Nature. 376: 37-43

Nicoletti I, Migliorati G, Pagliacci MC, Grignani F, Riccardi C (1991) A rapid and simple method for measuring thymocyte apoptosis by propidium iodide staining and flow cytometry. J. Immunol. Meth. 139: 271-275

Novelli F, Di Pierro F, Francia di Celle P, Bertini S, Affaticati P, Garotta G and Forni G (1994) Environmental signals influencing expression of the IFN- $\gamma$ receptor on human $\mathrm{T}$ cells control whether IFN- $\gamma$ promotes proliferation or apoptosis. $\mathrm{J}$ Immunol. 152: 496-504 
Pahlman S, Odelstat L, Larson E, Grotte G and Nilsson K (1981)Phenotypic changes of human neuroblastoma cells in culture induced by 12-0-tetradecanoylphorbol-13-acetate. Int. J. Cancer. 28: 583-589

Parodi MT, Cornaglia-Ferraris P and Ponzoni M (1989) Effects of $\gamma$-interferon on the growth, morphology and membrane and cytoskeletal protein expression of LAN1 cells. Exp. Cell Res. 185: 327-341

Perez-Polo JR, Werrbach-Perez K and Tiffany-Castiglioni A (1989) A human clonal cell line model of differentiating neurons. Dev. Biol. 71: 341-355

Philip T, Ladenstein R, Zucker JM, Pinkerton R, Bouffet E, Louis D, Siegert W, Bernard JL, Frappaz D, Coze C, Wyss M, Beck D, Souillet G, Michon J, Philip I, Chauvin F, Favrot M and Biron P (1993) Double megatherapy and autologous bone marrow transplantation for advnced neuroblastoma: the LMCE2 study. Br. J. Cancer. 67: 119-127

Piacentini M, Annichiarico-Petruzzelli M, Oliverio S, Piredda L, Biedler JL and Melino G (1992) Phenotype-specific 'tissue' transglutaminase regulation in human neuroblastoma cells in response to retinoic acid: correlation with cell death by apoptosis. Int. J. Cancer. 52: 271-278

Ponzoni M, Bocca P, Chiesa V, Decensi A, Pistoia V, Raffaghello L, Rozzo C and Montaldo PG (1995) Differential effects of N-(4-Hydroxyphenyl)retinamide and retinoic acid on neuroblastoma cells: apoptosis versus differentiation. Cancer Res. 55: 853-861

Ponzoni M, Casalaro A, Lanciotti M, Montaldo PG and Cornaglia-Ferraris P (1992) The combination of $\gamma$-Interferon and Tumor Necrosis Factor causes a rapid and extensive differentiation of human neuroblastoma cells. Cancer Res. 52: 931939

Ponzoni M, Melodia A, Cirillo C, Casalaro A and Cornaglia-Ferraris P (1988) Effect of cytosine arabinoside on the growth and phenotypic expression of GI-ME-N, a new human neuroblastoma cell line. In Advances in Neuroblastoma Research 2, Evans AE, D'Angio GJ, Knudson AJ and Seeger RC, eds. (New York: Alan R. Liss, Inc.) pp. 437-448

Pritchard J (1995) 'Megatherapy' for advanced neuroblastoma - Rationale and Role. Eur. J. Cancer. 31A: 134-136

Rodriguez-Villanueva J and McDonnel J (1995) Induction of apoptotic cell death in non-melanoma skin cancer by interferon- $\alpha$. Int. J. Cancer. 61: 110-114

Rupniak HT, Rein G, Powell JF, Ryder TA, Carson S, Povey S and Hill BT (1984) Characteristics of a new human neuroblastoma cell line which differentiates in response to cyclic adenosine 3':5'-monophosphate. Cancer Res. 44: $2600-$ 2607

Seeger RC, Danon YL, Rayner SA and Hoover F (1982) Definition of a Thy-1 determinant on human neuroblastoma, glioma, sarcoma and teratoma cells with a monoclonal antibody. J. Immunol. 128: 983-989

Selleri C, Sato T, Anderson S, Young NS and Maciejewski JP (1995) Interferon- $\gamma$ and tumor necrosis factor- $\alpha$ suppress both early and late stages of hematopoiesis and induce programmed cell death. J. Cell. Physiol. 165: 538-546
Sidell N (1982) Retinoic acid-induced growth inhibition and morphologic differentiation of human neuroblastoma cells in vitro

Steller H (1995) Mechanisms and genes of cellular suicide. Science. 267: 1445 1449

Tamura T, Ishihara M, Lamphier MS, Tanaka N, Oishi I, Aizawa S, Matsuyama T, Mak TW, Taki S and Taniguchi T (1995) An IRF-1-dependent pathway of DNA damage-induced apoptosis in mitogen-activated T lymphocytes. Nature. 376: $596-599$

Tanaka N, Ishihara M, Kitagawa M, Harada H, Kimura T, Matsuyama T, Lamphier MS, Aizawa S, Mak TW and Taniguchi T (1994) Cellular commitment to oncogeneinduced transformation or apoptosis is dependent on the transcription factor IRF1. Cell. 77: 829-839

Tarumi T, Sawada K, Sato N, Kobayashi S, Takano H, Yasukouchi T, Takahashi T, Sekiguchi S and Koike T (1995) Interferon- $\alpha$-induced apoptosis in human erythroid progenitors. Exp. Hematol. 23: 1310-1318

Thompson CB (1995) Apoptosis in the pathogenesis and treatment of disease. Science. 267: $1456-1462$

Trubiani O, Bosco D and Di Primio R (1994) Interferon- $\gamma($ IFN- $\gamma$ ) induces programmed cell death in differentiated human leukemic B cell lines. Exp. Cell Res. 215:, 23 27

Tumilowicz JJ, Nichols WW, Cholon JJ and Greene A (1970) Definition of a continuous human cell line derived from neuroblastoma. Cancer Res. 30:21102118

van Loon APGM, Ozmen L, Fountoulakis M, Kania M, Haiker M and Garotta G (1991) High-affinity receptor for interferon-gamma (IFN- $\gamma)$, a ubiquitous protein occurring in different molecular forms on human cells: blood monocytes and eleven different cell lines have the same IFN- $\gamma$ receptor protein. J. Leukoc. Biol. 49: $462-473$

Williams GT (1991) Programmed cell death: apoptosis and oncogenesis. Cell. 65: $1097-1098$

Wright SC, Kumar P, Tam AW, Shen N, Varma M and Larrick JW (1992) Apoptosis and DNA fragmentation precede TNF-induced cytolysis in U937 cells. J. Cell. Biochem. 48: 344-355

Wu AJ, Chen ZJ, Tsokos M, O'Connell BC, Ambudkar IS and Baum BJ (1996) Interferon-gamma induced cell death in a cultured human salivary gland cell line. J. Cell. Physioll. 167: 297-304

Wuarin L, Verity MA and Sidell N (1991) Effects of interferon- $\gamma$ and its interaction with retinoic acid on human neuroblastoma differentiation. Int. J. Cancer. 48: $136-$ 141 